\title{
OPTIMIZATION THE APPLICATION TIME OF BRADYRHIZOBIUM SP 3339 AS LIQUID INOCULATION ON NODULATION EFFICIENCY AND PEANUT GROWTH IN NEWLY RECLAIMED SANDY SOIL
}

\author{
H. M. EL Zemrany(1), E. A. Abou Hussein(1), A. Ab. Abo Elsoud(2) \\ and B. A. Abd Elgalel(2) \\ (1) Soil Sci. Dept., Fac. of Agric., Menoufia Univ., Egypt \\ (2) Soil, Water \& Environ. Res. Institute, Agric. Res. Center "ARC", Giza, Egypt.
}

Received: Sep. 6 , 2021

Accepted: Sep. 15, 2021

\begin{abstract}
The present work was conducted as a field experiment to evaluate the effect of timing application of the specific rhizobial (Bradyrhizobim sp 3339) as liquid inoculation with peanut plants and its some hybrids on the nodulation process, plant growth and seeds quality. This experiments were conducted at Om Saber Village-Tahrir Region - El Beheira Governorate, Egypt (Latitude $30^{\circ} .40^{\prime} \mathrm{N}$ - Longitude $30^{\circ} .33^{\prime} \mathrm{E}$ ) (represented newly reclaimed sandy soil). The experiment was carried on two cultivars i.e. Ponch and NC of the peanut seeds. The planting date was at 15 Mai 2019. All plots of liquid inoculation of each sub treatment were continuously inoculated with its specific rhizobial strain during the first "FW"), second "SW" and at the third week "TW" after sowing, through the dripping system. All plots of solid inoculation of each sub treatment were inoculated with its solid specific rhizobial strain (Bradyrhizobim sp 3339) (Okadin) just before sowing. The studied treatments were arranged with the experimental unit in completely block design in three replicates. Five main treatments: Control treatment (without any inoculation), solid inoculation "SI" at sowing and liquid inoculation which carried out through (via drip irrigation "Fertigation") at three times i.e. at "FW", "SW" and "TW" from sowing, were used in this study. Nodulation, dry weights of the growing shoot plants, seed and straw yield, as well shoots at 60 old day and seeds content of $N, P$ and $K$, were determined. The obtained results indicated that, the timing application of specific Rhizobial liquid inoculation (Bradyrhizobim sp 3339) of peanut plants, during FW and SW of sowing, were the most efficient inoculation treatments according to the high values of nodulation efficiency, macronutrients ( $N, P$ and $K$ ) concentrations and uptake by peanut plants (high significant) and produced the highest dry matter yields with all inoculation treatments compared to the control treatment.
\end{abstract}

Key words: Liquid inoculation, Solid inoculation, Bradyrhizobim sp 3339, Peanut plants, plant growth promoting rhizobacteria.

\section{INTRODUCTION}

The need for sustainable agricultural practices is revitalizing the worldwide interest in biological nitrogen fixation (BNF) and rhizobia- legume symbiosis, particularly in organic production system. Rhizobia-legume symbiosis is a complex process involving a set of plant and bacterial genes leading to the formation and development of root nodules on legume roots where rhizobia fix nitrogen from the atmosphere. About $60 \%$ of the Earth's available nitrogen is fixed via biological nitrogen fixation (BNF). The success of the symbiotic process depends on the competitiveness, specificity, compatibility, and effectiveness of rhizobia with its host legume under variable soil and environmental 
conditions. The application of appropriate rhizobia is considered an effective and environment-friendly approach which may profoundly increase the crop yield by different mechanisms of actions under variable conditions (Naveed et al., 2015).

Survival of rhizobia on legume seed is influenced by environmental factors leading to desiccation, exposure of macromolecules to toxic levels of $\mathrm{O}_{2}$ and high temperatures, and mobilization of inhibitory substances from the seedcoat. These factors interact to create a complex environment in which survival responses are difficult to interpret. Two main functions of carrier materials have been identified namely, they must support the growth of the organism and also support high viable numbers over an acceptable period of time. Despite awareness of the need to improve survival of rhizobia on inoculated seed, development of inoculant carriers remains focused on maximizing numbers of rhizobia to meet quality control standards, convenience and affordability. Unlike peat, there is little information about the ability of these alternative carriers to improve the subsequent survival of rhizobia on legume seed. Physiological and morphological changes during the maturation of the peat inoculant have been shown to affect survival. Poor survival on seed may be overcome by applying liquid and solid inoculants directly to soil. However, larger quantities of inoculant are generally required when liquid inoculation is used thereby increasing costs (Deaker et al., 2004).

In general, shortly after suspensions of Rhizobia are inoculated into the soil without a proper carrier, the bacterial population declines rapidly for most species of bacteria. This phenomenon, combined with poor production of bacterial biomass, difficulty sustaining activity in the rhizosphere, and the physiological state of the bacteria at application time, can prevent the buildup of a sufficiently large bacteria population in the rhizosphere. A threshold number of cells, which differs among species, is essential to obtain the intended positive plant response, for example, $10^{6}-10^{7}$ cells plant $^{-1}$ for the rhizobia. The inherent heterogeneity of the soil is the key obstacle, where introduced bacteria sometimes cannot find an empty niche in the soil. These unprotected, inoculated bacteria must compete with the often better-adapted native microflora and withstand predation by soil microfauna. Consequently, a major role of formulation of inoculants is to provide a more suitable microenvironment, combined with physical protection for a prolonged period to prevent a rapid decline of introduced bacteria. Inoculants for fieldscale use have to be designed to provide a dependable source of bacteria that survives in the soil and become available to crops, when needed (Bashan et al., 2014).

Liquid inoculants are an upgraded derivative of "no formulation" inoculants to address some of the limitations. Essentially, they are microbial cultures or suspensions amended with substances that may improve stickiness, stabilization, and surfactant and dispersal abilities (Singleton et al., 2002). The main advantage of these inoculants over solid inoculants is that they are easy to handle. Unlike solid carrier- based inoculants, liquid formulations allow the manufacturer to include sufficient amounts of nutrients, cell protectants, and inducers responsible for cell/spore/cyst formation to improve performance. While the shelf life of common solid carrier-based inoculants is $\sim 6$ months (or in the best of cases, 12-18 months), another advantage of a liquid formulation is that its shelf life could be as high as $\mathbf{2}$ years. They have a few major 
disadvantages: (1) Limited shelf life in some cases (but not for all), (2) Cool or cold conditions are required for longterm storage, and (3) Increased costs, a fact that limits their use to developed countries and precludes use in most developing countries. They gained popularity in developed countries for legume inoculation because of high cell counts. Liquid inoculants containing concentrations of $2 \times 10^{9}$ cells per $\mathrm{mL}$ are now common, allowing for lower application rates and increased efficiency in using inoculants (Schulz and Thelen, 2008). Further, it is claimed that these inoculants have no contamination and have longer shelf life for some formulations, greater protection against environmental stresses, and increased field efficacy, compared to peat-based inoculants (Singleton et al., 2002). They are compatible with large and small farms via drip irrigation. This method ensures even coverage of the seeds without interference with the seed monitoring system of the planters or inoculum loss when dried.

The aim of this study were: Evaluation the effect of the timing application of the specific rhizobial liquid inoculation with peanut plants on the nodulation process. c) Evaluation the response of some hybrids of the peanut plants to the timing application of its specific rhizobial liquid inoculation (Bradyrhizobim sp 3339), and d) Reflection between the response of peanut plants and their hybrids to the timing application of Bradyrhizobim $s p$ 3339 on the peanut plant growth and crop quality.

\section{MATERIALS AND METHODS}

\section{A. MATERIALS}

\section{Soil location and soil sampling}

Before planting of the cultivated peanut plants, surface 5 soil samples (0$20 \mathrm{~cm}$ ) were taken from the experimental site of the same farm located at Om Saber Village -Tahrir region (Latitude $30^{\circ} .40^{\prime} \mathrm{N}$ - Longitude $30^{\circ} .33^{\prime} \mathrm{E}$ ) - Beheira Governorate, Egypt and air-dried, ground, good mixed and sieved through a $2 \mathrm{~mm}$ sieve. The fine and sieved soil ( $>2$ $\mathrm{mm}$ ) was analysed for some physical and chemical properties were determined according to Klute (1986), Cottenie et al. (1982) and Page et al. (1982). The obtained data are recorded in Table (1).

\section{Inoculum preparations of the rhizobial specific strains}

The used Inoculum to these experiments was obtained by growing the specific rhizobial strain (Bradyrhizobim sp 3339) on Yeast Mannitol Broth (YMB) medium (Vincent, 1970). Bradyrhizobim sp 3339 was maintained in YMB and cultured routinely at $28^{\circ} \mathrm{C}$ on a rotary shaker operating at 65 cycles $\min ^{-1}$ overnight. The cells were washed once in sterile distilled water and the cell suspensions adjusted to $2.8 \times 10^{7}$ cell $\mathrm{ml}^{-1}$ based on OD readings (an OD595 of 1 is equivalent to $10^{9}$ cells ml-1).

\section{Liquid inoculation process}

All plots of Bradyrhizobim sp liquid inoculation of each sub treatment were continuously inoculated with its specific rhizobial strain at $\mathbf{0 - 7 ^ { \text { th } }}$ (first week "FW"), $8-14^{\text {th }}$ (second week "SW") and $15-21^{\text {th }}$ (third week "TW") days after sowing, through the dripping system.

\section{Solid inoculation process}

All plots of solid inoculation of each sub treatment were inoculated with its solid specific rhizobial strain Bradyrhizobim sp 3339 (Okadin) just before sowing. The solid inoculation was performed by coating the seeds of peanut plants at a rate of $800 \mathrm{gm}$ of solid inoculum $\mathrm{fed}^{-1}$. The Biofertilizer Bradyrhizobim sp 3339 (Okadin) (specific for peanut plants) were kindly provided from Lab of Microbiology, Soil, Water and Environment Research Institute (SWERI), Agriculture Research Center (ARC), Giza, Egypt. 
Table (1): Physical and chemical properties and nutrient contents of the soil in the field experiment at Om Saber-Tahrir regions-Behera Governorate, Egypt

\begin{tabular}{|c|c|c|}
\hline Property & Unit & Value \\
\hline Particle fraction: & $\%$ & $\begin{array}{c}77.33 \\
13.43 \\
9.24\end{array}$ \\
\hline Textural grade & & Sandy loam \\
\hline Field capacity & $\%$ & 19.68 \\
\hline Organic matter & $\%$ & 0.78 \\
\hline $\begin{array}{l}\text { pH (1:2.5 soil/ water } \\
\text { suspension) }\end{array}$ & & 7.83 \\
\hline $\begin{array}{l}\text { E.C ( } 1: 5 \text { soil:water } \\
\text { extract) }\end{array}$ & $\mathrm{dSm}^{-1}$ & 1.21 \\
\hline Soluble cation: & \multirow{10}{*}{ 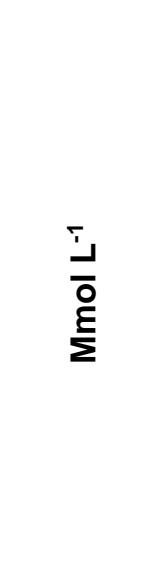 } & \\
\hline $\mathrm{Na}^{+}$ & & 6.52 \\
\hline $\mathrm{K}^{+}$ & & 4.72 \\
\hline $\mathrm{Ca}^{++}$ & & 0.80 \\
\hline $\mathbf{M g}^{++}$ & & 0.60 \\
\hline Soluble anion: & & \\
\hline $\mathrm{Cl}^{-}$ & & 8.62 \\
\hline $\mathrm{HCO}_{3}^{-}$ & & 0.40 \\
\hline $\mathrm{CO}_{3}^{--}$ & & 0.00 \\
\hline $\mathrm{SO}_{4}^{--}$ & & 3.62 \\
\hline Total $\mathrm{CaCO}_{3}$ & \multirow{4}{*}{$\mathrm{g} \mathrm{Kg}^{-1}$} & 36.20 \\
\hline Total N & & 1.50 \\
\hline Total $\mathbf{P}$ & & 1.40 \\
\hline Total $\mathrm{K}$ & & 1.70 \\
\hline \multirow{3}{*}{$\begin{array}{r}\text { Available macronutrient: } \mathrm{N} \\
\mathrm{P} \\
\mathrm{K}\end{array}$} & \multirow{6}{*}{$\mathrm{mg} \mathrm{kg}^{-1}$} & 46.70 \\
\hline & & 3.10 \\
\hline & & 55.46 \\
\hline \multirow{3}{*}{$\begin{array}{r}\mathrm{Fe} \\
\text { Available micronutrient: } \mathrm{Mn} \\
\mathrm{Zn}\end{array}$} & & 3.80 \\
\hline & & 4.79 \\
\hline & & 0.84 \\
\hline
\end{tabular}

\section{B. The experimental treatments}

The experimental treatments in this study were arranged within the experimental units in spilt randomized block design in three replicates illustrated in Diagram (1) as follows: 
Diagram (1): The experimental design (for one replicate) and Appling treatments.

\begin{tabular}{|c|c|c|c|c|c|c|c|c|c|}
\hline \multicolumn{6}{|c|}{ Liquid Inoculation } & \multirow{2}{*}{\multicolumn{2}{|c|}{$\begin{array}{l}\text { Solid } \\
\text { Inoculation } \\
\text { "SI" }\end{array}$}} & \multirow{2}{*}{\multicolumn{2}{|c|}{$\begin{array}{c}\text { Control } \\
\text { "Without any } \\
\text { inoculation" }\end{array}$}} \\
\hline \multicolumn{2}{|c|}{ "FW" } & \multicolumn{2}{|c|}{ "SW" } & \multicolumn{2}{|c|}{ "TW" } & & & & \\
\hline Ponch & NC & Ponch & NC & Ponch & NC & Ponch & NC & Ponch & NC \\
\hline
\end{tabular}

Where: "SI": Solid inoculation at 0-time, SW, SW" and TW: Liquid inoculation at first, second and third week after sowing, respectively. Ponch and NC: the peanut cultivars plant.

\section{a-Main treatments:}

Five main treatments: i.e control treatment (without any inoculation), solid inoculation "SI" at sowing and liquid inoculation which carried out through (via drip irrigation "Fertigation") at three times i.e. at "FW"), "SW" and "TW" after sowing, were used in this study.

\section{b- Sub-treatments:}

These sub treatments represented by the two peanut cultivar plants i.e. Ponch and NC".

\section{Field Experiment}

Afield experiment was conducted at Om Saber Village-Tahrir Rregions - EI Beheira Governorate, Egypt (Latitude $30^{\circ} .40^{\prime} \mathrm{N}$ - Longitude $30^{\circ} .33^{\prime} \mathrm{E}$ ) (sandy loam soils represented newly reclaimed soil). The area of each plot was $10.5 \mathrm{~m}^{2}$ $(3.5 \times 3 \mathrm{~m})$. The planting dates were at 15 Mai, 2019.

Seeds of peanut plants was planted at a rate of $45 \mathrm{Kg}$ seeds $\mathrm{fed}^{-1} .60 \mathrm{~cm}$ row and $25 \mathrm{~cm}$ distance between the plants. Just before sowing, the seeds of each plot of the solid inoculation "SI" treatments were inoculated with Bradyrhizobim sp 3339 solid inoculum (Okadin). After sowing, the plots of the liquid inoculation treatment, were divided into to three groups. The first group were received their liquid inoculation with Bradyrhizobim sp 3339 through the first week "FW". The second and the third groups were received the Bradyrhizobim sp 3339 liquid inoculation through second week "SW" and third week "TW" after sowing, respectively. Inoculum level was approximately $10^{9} \mathrm{cfu}^{\mathrm{ceed}}{ }^{-1}$. The seeds were sown under drip irrigation system, where irrigation was carried out as soil field capacity.

The normal cultural practices of peanut plants, i.e. irrigation, mineral and organic fertilization and pest control were followed according to recommendation of Egyptian Ministry of Agriculture.

After 45 and 60 days of sowing, three plants of each replicate representing the studied treatments (9 plants for each treatment) were taken randomly. The plants of each sample at 45 old days were leached genteelly using tap water to remove the soil particles. The bacterial nodules formed on the root of each crop plants were counted, weighted and recorded (g) plant. Also, the shoots of the harvested plants at 60 old days were air dried and oven dried at $70{ }^{\circ} \mathrm{C}$ for $72 \mathrm{hrs}$. and weighed to obtain the dry matter yield of shoots, subjected to chemically analyzed to determine their content of $\mathrm{N}$, $P$ and $K\left(\%\right.$ and $\left.\mathrm{Kg} \mathrm{fed}^{-1}\right)$.

At harvest stag (130 days after sowing) the seeds of each replicate of the one plot $\left(10.5 \mathrm{~m}^{2}\right)$ were taken as a whole to determine yield of seeds $\left(\mathrm{Kg} \mathrm{fed}^{-1}\right)$. A portion of each plant sample (seeds) was oven dried at $70{ }^{\circ} \mathrm{C}$ for $72 \mathrm{hrs}$., ground and kept in dried and clean glass bottles up to chemically analyzed to their content of $\mathrm{N}, \mathrm{P}$ and $\mathrm{K}\left(\%\right.$ and $\left.\mathrm{Kg} \mathrm{fed}^{-1}\right)$. which carried out according to Chapman and Pratt (1961). Data of the present 
study were statistically analyzed using COSTATE Computer Software, according to Gomez and Gomez (1984). Significant differences among treatments means were determined at $P \leq 0.05$ by using LSD test and Duncan's Multiple Comparisons Test.

\section{- Relative changes "RC\%" of the obtained data}

Rates of the relative changes "RC\%" of the final results (as percent) were calculated for the result tabulated for a particular sub-treatment, referring to the result of the specific control (without inoculation).

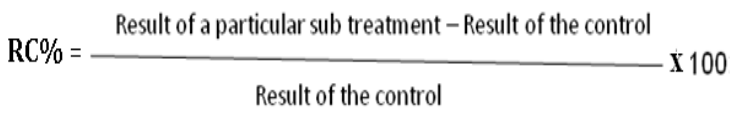

\section{RESULTS AND DISCUSSION}

\section{Number and dry weight of nodules}

Data presented in Table (2) pointed out the effect of application time of inoculation treatments with liquid Bradyrhizobium sp 3339 on the number (nodule plant ${ }^{-1}$ ) formed on the roots of peanut plants and their dry weight (mg plant $^{-1}$ ) of nodules and their relative changes "RC" (\%), after 45 days after sowing. The inoculation treatments of the liquid Bradyrhizobium sp. 3339 at the FW had high increases both number of nodules and their dry weight in comparison to other liquid or solid inoculation treatments. This trend was found with the two peanut cultivars. The maximum number and weight nodules were observed with the liquid Bradyrhizobium sp. 3339 application during the $\mathrm{FW}$ of sowing compared to the "SW", "TW" and "SI" treatments. Where the correspondence values of number and weight nodules were 37.33 and 660.67 for Ponch cultivar. whereas, for the NC cultivar were 40.00 and $\mathbf{9 1 1 . 5 0 ,}$ respectively.
It is important to mention that, when liquid Bradyrhizobium sp applied at TW after sowing, the seeds have passed the germination period, consequently, did not affect the nodule numbers and not affecting on the symbiotic effectiveness.

The calculated values of RC \% (relative change) of the nodules number and its dry weight, recorded in Table (2) displayed that, all values of RC were higher under the liquid Bradyrhizobium sp. treatments at FW and SW after sowing, with both the two studied peanut cultivars than those found with other experimental treatments. Where, the maximum RC \% values of nodules number were obtained with the liquid inoculation at FW after sowing, where this value were 7.67 and $22.44 \%$ of nodule number and 74.32 and $70.37 \%$ for nodule dry weight, formed on the roots of Ponch and NC peanut roots cultivar, respectively. These observations were in similar with data reported by Zhang et al. (2016), who reported that, the mechanisms of nodulation enhancement have been extensively studied, mainly including production of phytohormones, especially indole acetic acid (IAA), excretion of nod genes inducing flavonoids and alterations of root morphology. The liquid Bradyrhizobium $s p$. could produce IAA in vitro. Thus, it may be assumed that Bradyrhizobium sp can enhance peanut-rhizobium nodulation. Meanwhile, the peanutrhizobium nodulation is mainly occurred at the junction of the primary and secondary roots. Therefore, more lateral root formation can provide more potential rhizobial invasion sites, and thus enhance nodulation, In addition, there is a considerable risk of high rates of inoculant mortality when solid inoculant (SI) is applied to seed as much as $24 \mathrm{~h}$ (or more) in advance of seeding (Brockwell et al., 1995). In addition, liquid formulations allow high cell concentration void of contaminants and 


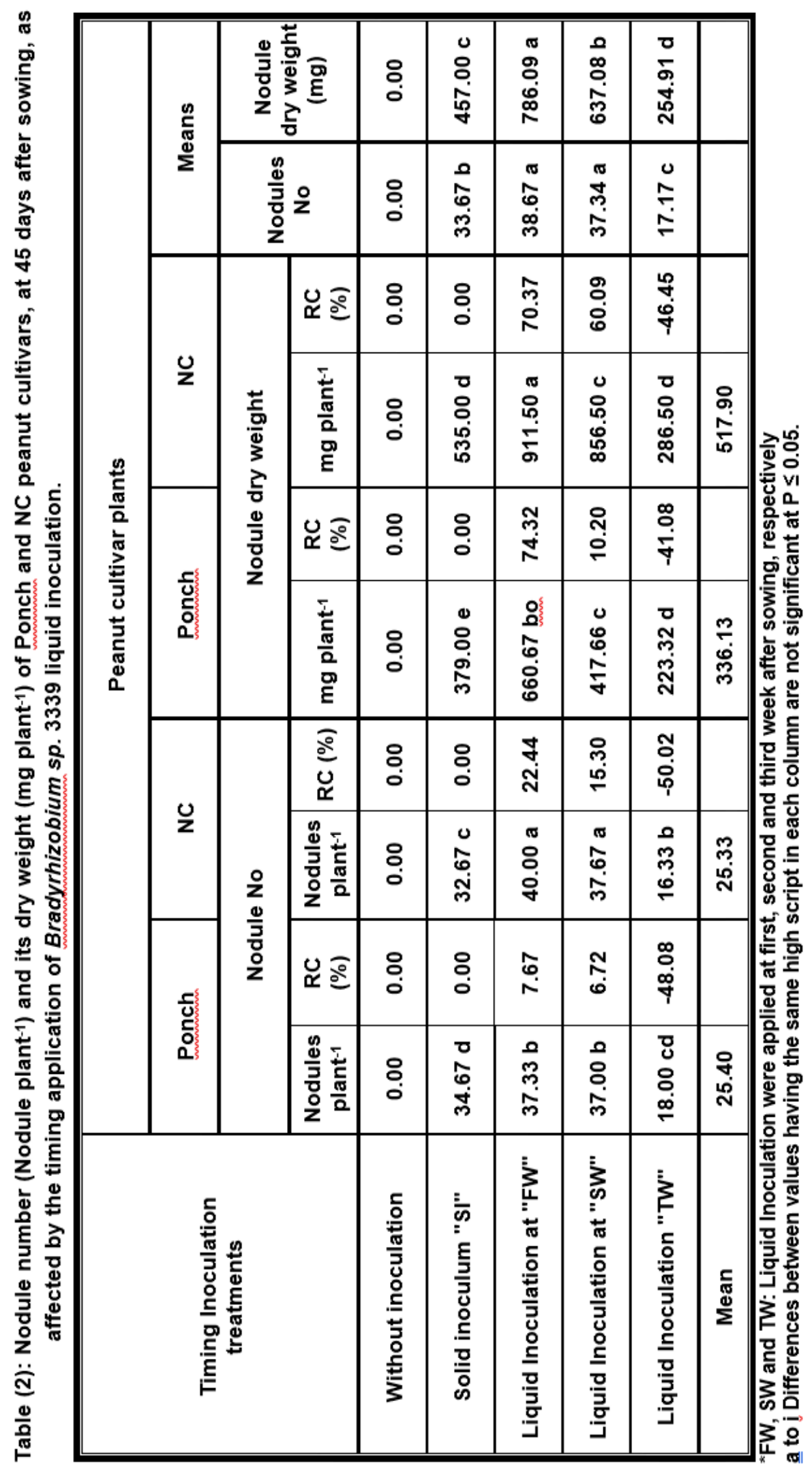


are preferred by farmers due to ease in application of seeds or in-furrow (Yates et al., 2016). Zommere and Nikolajeva. (2017) postulated that, application of liquid microbial inoculants on legume seeds is a sustainable agricultural practice that can improve plant nutrient uptake and increase crop productivity.

\section{Dry matter yields (DMY) of peanut shoot plants}

The presented data in Table (3) and shown in Fig. (1) show the dry matter yield $\left(\mathrm{Mg} \mathrm{fed}^{-1}\right)$ of shoots after $\mathbf{6 0}$ days of sowing of two peanut cultivar grown on sandy soil in relation to solid or liquid application of Bradyrhizobium sp. at FW, SW and TW of sowing, these data show that, the treatments of inoculation with the liquid application of Bradyrhizobium sp. at FW, and SW after sowing, resulted in a significantly increase of dry (DMY) shoots of both studied peanut cultivar. The obtained dry matter yield of NC peanut cultivar was higher than those found with Ponch cultivar under all studied inoculation treatments. The highest value of shoots DMY was $5.79 \mathrm{Mg}$ fed $^{-1}$ for the plants of Ponch inoculated with the liquid Bradyrhizobium sp. at FW, where these values was11.37 $\mathrm{Mg} \mathrm{fed}^{-1}$ for DMY of NC peanut cultivar, under the same abovementioned liquid inoculation treatment, respectively.

Concerning the RC (\%) values of DMY peanut shoot plants, the highest RC values were obtained with the liquid inoculation with Bradyrhizobium sp. 3339 for the first, second and third weeks after sowing, treatments. With the same inoculation treatment, the plants of NC were attained higher RC values of DMY compared to those found with Ponch cultivar. These results are in accordance with the findings of El-Sayed et al. (2016). who reported that, inoculation with Bradyrhizobium sp. and plant growth promoting rhizobacteria improved plant growth parameters, of peanut plants. It has been suggested that liquid inoculants delivered deeper in the soil, may be exposed to greater moisture, which could improve rhizobial survival and nodulation (Kyei-Boahen et al., 2002).

Table (3): Dry matter yields (DMY) ( $\mathrm{Mg} \mathrm{fed}^{-1}$ ) of Ponch and NC cultivars peanut plants, at 60 days after sowing, as affected by the timing application of Bradyrhizobium sp 3339 liquid inoculation.

\begin{tabular}{|c|c|c|c|c|c|}
\hline \multirow{3}{*}{ Inoculation treatments } & \multicolumn{5}{|c|}{ Peanut cultivar plants } \\
\hline & \multicolumn{2}{|c|}{ Ponch } & \multicolumn{2}{|c|}{ NC } & \multirow{2}{*}{ Mean } \\
\hline & Mg fed $^{-1}$ & RC & $\mathrm{Mg} \mathrm{fed}^{-1}$ & RC & \\
\hline Without inoculation & $2.00 \mathrm{~d}$ & 0.00 & $2.40 \mathrm{e}$ & 0.00 & $2.20 \mathrm{e}$ \\
\hline Solid inoculum "SI" & $5.10 \mathrm{~b}$ & 155.00 & $8.06 \mathrm{~b}$ & 235.83 & $6.58 \mathrm{a}$ \\
\hline Liquid Inoculation at "FW" & $5.79 \mathrm{bc}$ & 189.50 & $11.37 \mathrm{a}$ & 373.75 & $8.58 \mathrm{~b}$ \\
\hline Liquid Inoculation at "SW" & $5.57 \mathrm{bc}$ & 178.34 & $8.50 \mathrm{~b}$ & 254.17 & $7.03 \mathrm{bc}$ \\
\hline Liquid Inoculation at "TW" & $3.97 \mathrm{bc}$ & 98.50 & $6.62 \mathrm{~d}$ & 175.83 & $5.29 \mathrm{~d}$ \\
\hline Mean & 4.49 & & 7.39 & & \\
\hline
\end{tabular}

*FW, SW and TW: Liquid Inoculation were applied at first, second and third week after sowing, respectively. $a$ to i Differences between values having the same high script in each column are not significant at $P \leq 0.05$. 


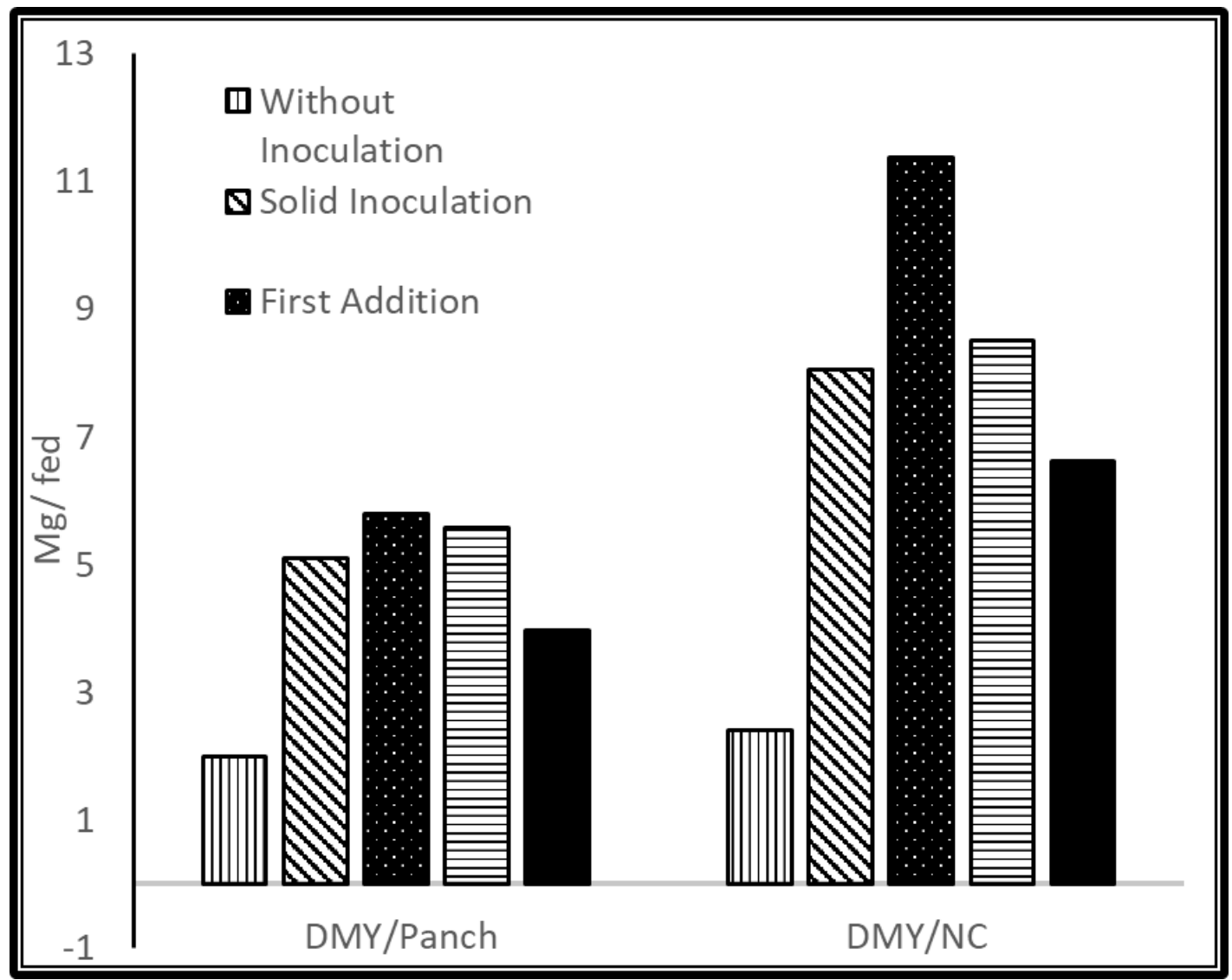

Fig (1): Dry matter yields (DMY) $\left(\mathrm{Mg} \mathrm{fed}^{-1}\right)$ and their RC values \% of Ponch and NC cultivars peanut plants, at 60 days after sowing, as affected by the timing application of Bradyrhizobium sp 3339 liquid inoculation.

3. Shoots content of macronutrients. a- Nitrogen ( $\mathrm{N}$ ) content

Data listed in Table (4) show a significant increase in the content of $\mathrm{N}, \mathrm{P}$ and $\mathrm{K}\left(\%\right.$ and $\left.\mathrm{Kg} \mathrm{fed}^{-1}\right)$ in shoots of both cultivars peanut plants due to the inoculation with solid or liquid Bradyrhizobium sp under all treatments compared to the uninoculated (control) treatments. The inoculation treatment with the liquid Bradyrhizobium sp. 3339 at FW, and SW after sowing, induced the maximum values of nitrogen content (\%) and $\mathrm{Kg} \mathrm{fed}^{-1}$ ) of both cultivars (Ponch and $\mathrm{NC}$ ), where these treatments were associated by $\mathrm{N}$ contents of 3.029 and 2.99\%, which equal to 174.96 and 166.17 $\mathrm{Kg} \mathrm{fed}^{-1}$ of Ponch cultivar, increased to 3.54 and $3.23 \%$ which equal to 401.87 and
$274.14 \mathrm{Kg} \mathrm{fed}-1$ of NC cultivar, respectively. It was noticed that nitrogen content (\%) and its uptake as $\mathrm{Kg} \mathrm{fed}^{-1}$ at FW have a high and significant value compared with these found at SW and TW.

Recorded RC values in Table (4) reveal that, the shoot of peanut plants inoculation by liquid Bradyrhizobium sp at FW, and SW achieved the highest values of $\mathrm{RC}$ of $\mathrm{N}$ uptake compared to that at SI or TW treatments. Also, RC \% values of $\mathrm{N}$ uptake by the plants of NC cultivar were higher those found with the plants of Ponch cultivar under all studied treatments. Meanwhile, the highest values of RC $(572.07 \%)$ of nitrogen uptake in shoots of NC cultivar was obtained with the inoculation treatments 


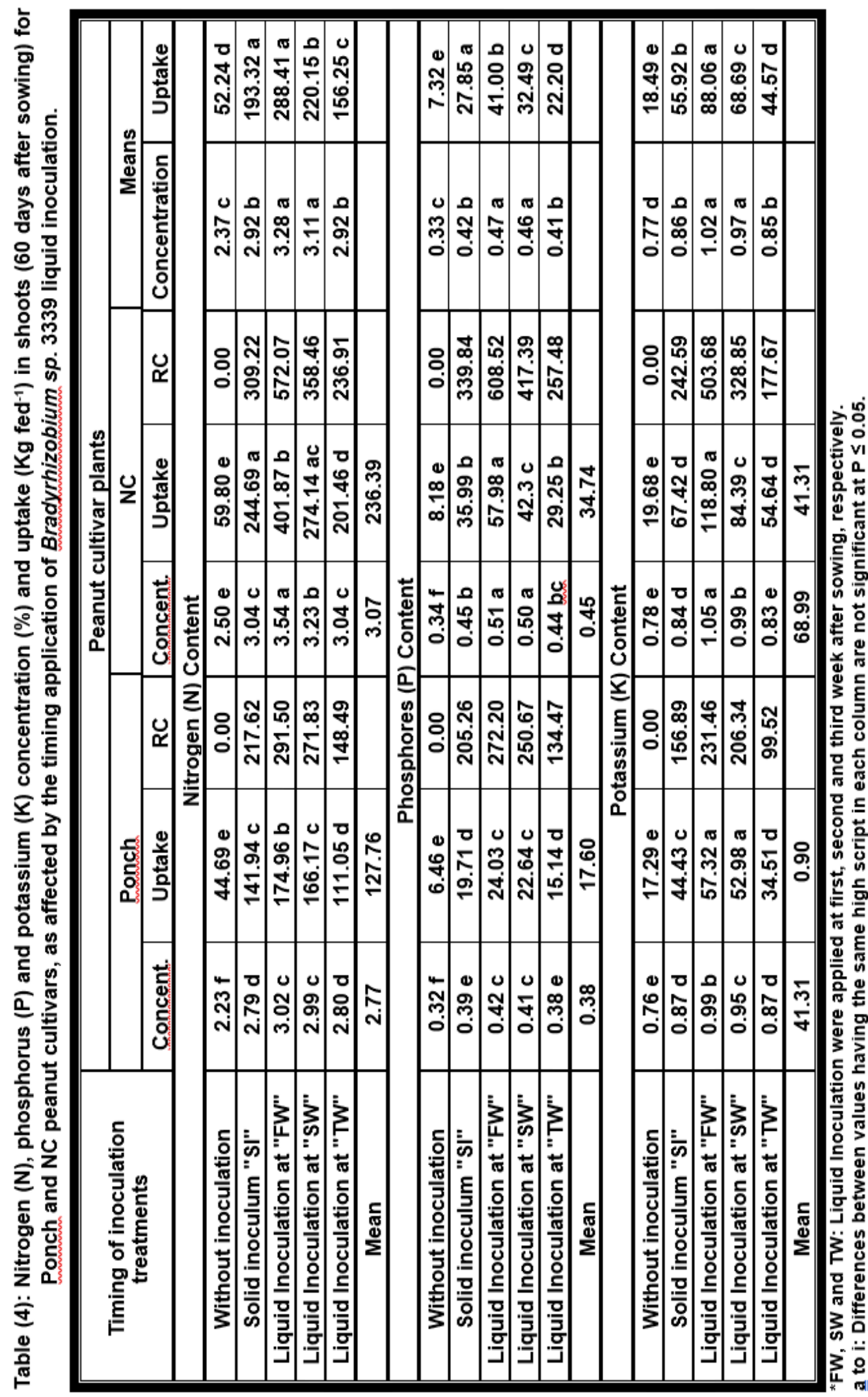


with liquid Bradyrhizobium sp. 3339 at $F W$. The superiority increase effect of the inoculation treatments with liquid Bradyrhizobium sp. 3339 at FW on N content was confirmed in this study, where it consistently resulted in the highest nodulation, plant growth, $\mathrm{N}$ accumulation in shoots.

\section{b. Phosphorus $(\mathrm{P})$ contents}

Phosphorus content (\%), uptake (Kg fed $^{-1}$ ) and RC values of uptake $P$ in shoots (60 days after sowing) of Ponch and NC cultivar are listed in Table (4). There data demonstrated that, all inoculation treatments (solid or liquid) significantly increased $P$ content in the two cultivars of peanut plants compared to the non-inoculation treatments. The inoculated plants with liquid Bradyrhizobium sp. at FW after sowing, appeared a high $P$ content in shoots of the two cultivars of peanut plants. In regarding to Ponch and NC cultivar peanut plants, inoculated with liquid Bradyrhizobium sp. at FW after sowing, led to maximum values of $P$ uptake by shoots which was: 24.03 and $57.98 \mathrm{Kg}$ fed $^{-1}$, respectively.

Values of RC of phosphorus uptake in the shoots of both cultivars presented in Table (4) manifest that, the inoculation treatments of both cultivar by liquid Bradyrhizobium sp. at "FW" after sowing, had a high RC values of $P$ uptake. However, the inoculation of NC with the same inoculation treatments exhibited a higher RC values $(608.52 \%)$ of $P$ uptake in compared with found with the plants of Ponch (272.20\%).

\section{c. Potassium (K) contents}

Data of $\mathrm{K}$ content (\% and $\mathrm{Kg} \mathrm{fed}^{-1}$ ) in Table (4) denote that, both cultivar of peanut plants inoculated with solid or liquid Bradyrhizobium sp. led to a significant increase in $K$ content of the plants. (shoots) The inoculation treatments with liquid Bradyrhizobium sp. at FW after sowing, significantly augmented $K$ uptake in shoots of peanut plants compared to the other solid or liquid inoculation treatments, The plants inoculated with the same inoculation treatments inoculation through $\mathrm{FW}$ gave a higher values of $\mathrm{K}$ contents in shoots i.e. 0.99 and $1.05 \%$ which equal to 57.32 and $118.80 \mathrm{Kg} \mathrm{fed}^{-1}$ of Ponch and NC cultivar plants, respectively.

In addition, RC values of potassium uptake in the shoots of peanut plant listed in Table (4) noted that, plants inoculated with the liquid Brabdyrhizobium spp. at FW and SW after sowing had a high RC values of $K$ uptake in the two cultivars of peanut plants in compared to the solid inoculation treatments. Meanwhile, the same bacterial inoculum which applied through FW after sowing, attained high $\mathrm{RC}, \%$ values of $\mathrm{K}$ uptake in Ponch and NC plants.

\section{Seed and straw yields}

Data in Table (5) intimate that seed and straw yields $\left(\mathrm{Kg} \mathrm{fed}^{-1}\right)$ of Ponch and NC cultivars of peanut plants were affected widely by studied inoculation treatments. In general, the inoculation treatments by solid or liquid Bradyrhizobium sp 3339 significantly augmented seed and straw yields of Ponch and NC cultivars compared to the uninoculated plants. Inoculation with liquid Bradyrhizobium sp. 3339 treatments during $\mathrm{FW}$ and SW after sowing, gained a higher seed yield 1551.21 and $1438.49 \mathrm{Kg} \mathrm{fed}^{-1}$ and 1682.17 and $1483.58 \mathrm{Kg} \mathrm{fed}^{-1}$ of Ponch and NC cultivars peanut plants, at FW and SW respectively. Similar increase effect of liquid inoculation treatments was found with straw yields of the examined peanut cultivar. It is clear from data listed in Table (5) that NC cultivar showed the highest values of seed and straw yields compared to those with Ponch cultivar with all the studied treatments. 


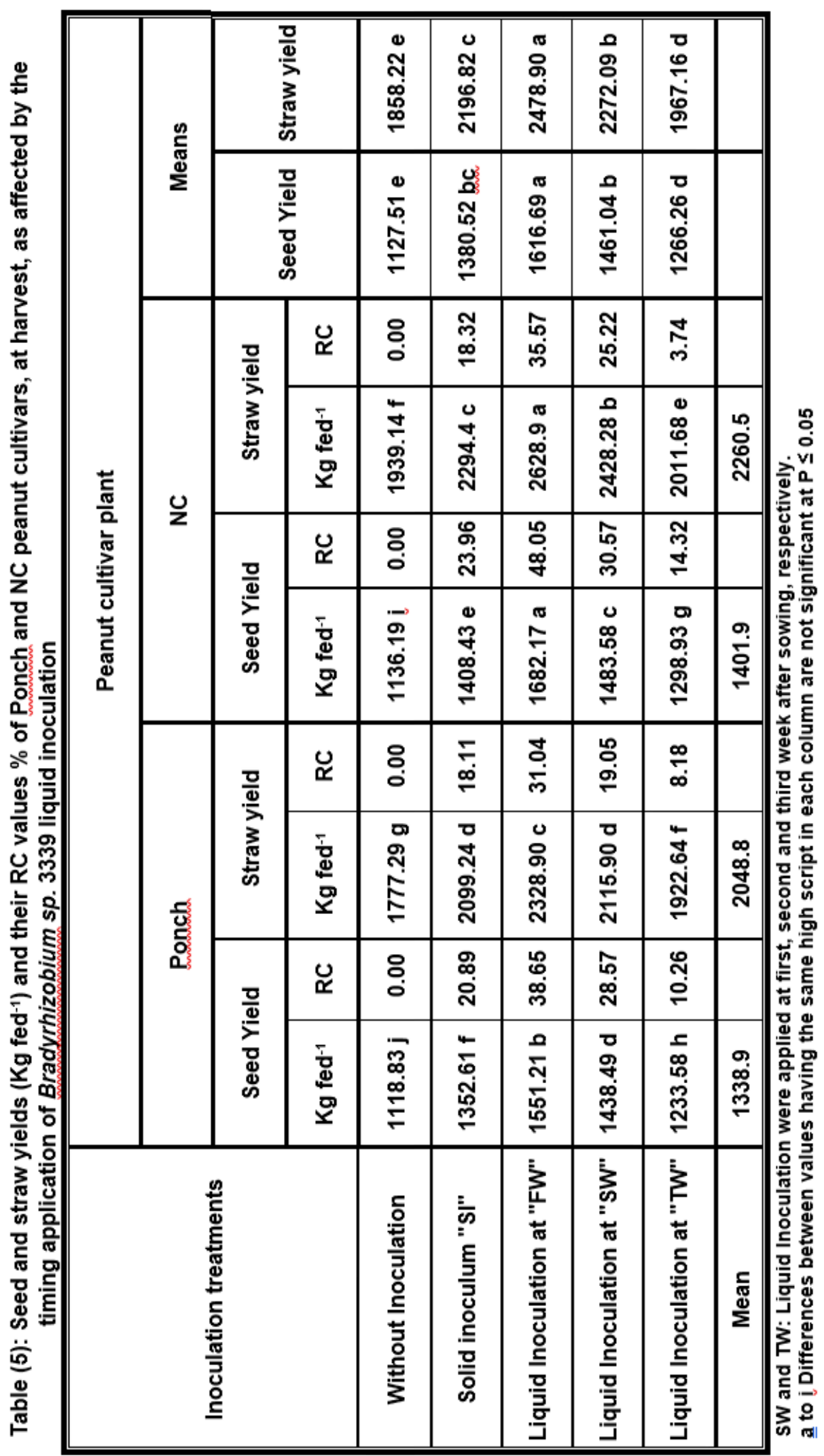


Relatives change RC calculated for seed and straw yields $\left(\mathrm{Kg} \mathrm{fed}^{-1}\right)$ of Ponch and NC cultivars of peanut plants, generally stimulated as a result of the liquid inoculation during FW and SW after sowing, treatments in compared to the SI and TW treatments (Table 5). In respect to $\mathrm{RC} \%$, values of seeds and straw yields affected by inoculation treatments of liquid Bradyrhizobium sp within FW and SW after sowing, were higher, where its values were: $\mathbf{3 8 . 6 5}$ and $28.57 \%$ with the plants of Ponch cultivar, and 48.05 and $30.57 \%$ with the plants of NC cultivar, respectively. It is worth mention that the results of straw yields take the same trend of the seed yields with the same abovementioned liquid inoculation treatments.

\section{Seed content of macronutrients}

\section{a-Nitrogen $(\mathrm{N})$ content}

Nitrogen content $\left(\mathrm{g} \mathrm{Kg}^{-1}\right.$ and $\left.\mathrm{Kg} \mathrm{fed}^{-1}\right)$ in the seeds of peanut plants cultivated in sandy soil. As well as the relative change "RC" (\%) of $\mathrm{N}$ uptake affected by the solid or liquid inoculation by Bradyrhizobium sp. 3339 were studied and the found data recorded in Table (6). Data appeared that, there are widely varied within $\mathrm{N}$ content according to the planted cultivars and type and applying times of the liquid inoculation. For example, with all inoculation studied treatments $\mathrm{N}$ content $\left(\mathrm{g} \mathrm{Kg}^{-1}\right.$ and $\left.\mathrm{Kg} \mathrm{fed}^{-1}\right)$ in the seeds of NC cultivars was higher than that found in the seeds of Ponch cultivar plats. Generally, applications of liquid inoculation by Bradyrhizobium sp. 3339 during FW and SW after sowing, resulted in a significant increase of grins $\mathrm{N}$ content (\%) and the relative change "RC" of its uptake. These findings related with the effect of liquid inoculation at FW and SW after sowing. These finding resulted from the increase of $\mathrm{N}$ availability in the soil and its uptake by plants. These results are in similar with these found by El Zemrany et al. (2019). Liquid applications of Bradyrhizobium sp. 3339 at "FW" after sowing resulted in a maximum increase in the seed content of $\mathrm{N}$ with, where this content with the plants of NC was: $59.00 \mathrm{~g} \mathrm{Kg}^{-1}$ and 99.25 $\mathrm{Kg} \mathrm{fed}^{-1}$ and were the $56.00 \mathrm{~g} \mathrm{Kg}^{-1}$ and $86.87 \mathrm{Kg} \mathrm{fed}^{-1}$ of Ponch cultivar (Table 6).

\section{b-Phosphorus $(P)$ content:}

Data listed in Tables (6) display $P$ concentration $\left(\mathrm{g} \mathrm{Kg}^{-1}\right)$ and uptake $(\mathrm{Kg}$ $\mathrm{fed}^{-1}$ ) as well as the relative changes "RC $\% "$ of its uptake, by the seeds of peanut plants, affected by inoculation with the solid or liquid of Bradyrhizobium $s p$. 3339. Results showed that $P$ concentrations and uptake by peanut seeds significantly increased with solid or liquid Bradyrhizobium sp. $\mathbf{3 3 3 9}$ inoculation treatments compared to the uninoculated plants.

The plants inoculated with the liquid Bradyrhizobium sp. 3339 during FW of sowing, attained the highest seed phosphorus concentration $\left(\mathrm{g} \mathrm{Kg}^{-1}\right)$ and uptake $\left(\mathrm{Kg} \mathrm{fed}^{-1}\right)$ in compared to the seeds of plants received the other inoculation treatments in this study (Table 6). The highest seeds $\mathrm{N}$ content were found in the plants inoculated with the liquid Bradyrhizobium sp. 3339 during FW and SW of sowing, where these values were, 7.53 and $7.81 \mathrm{~g} \mathrm{Kg}^{-1}$ which equal 11.68 and $13.14 \mathrm{Kg} \mathrm{fed}^{-1}$ of Ponch and NC cultivars.

Values of the relative changes "RC, $\% "$ of $P$ uptake by the seeds of peanut plantas recorded in (Table 6) show that, the treatments of the liquid Bradyrhizobium sp. 3339 during FW and SW of sowing, were associated with the highest values of $\mathrm{RC} \%$, in compared to the RC values of the inoculation during $\mathrm{SI}$ and TW of sowing. Meanwhile, the RC values for liquid Bradyrhizobium sp. 3339 treatment during FW of sowing, were higher than above noted other 


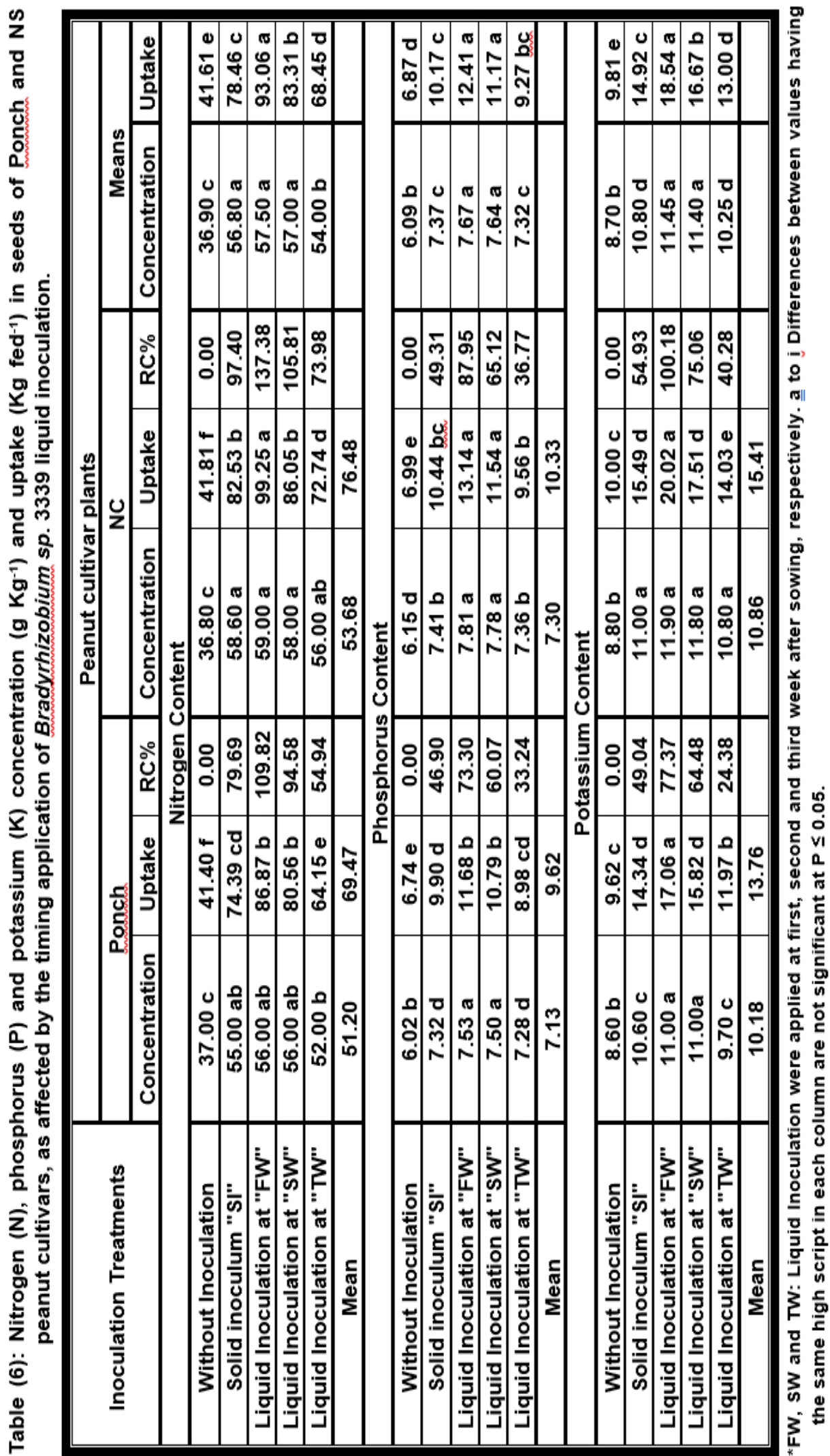


inoculation treatments in this study, where this found RC value were: $73.30 \%$ and $87.95 \%$ in the seeds of Ponch and NC cultivar respectively.

\section{c-Potassium (K) content:}

Data of the impact of timing application of liquid Bradyrhizobium sp. 3339 on $\mathrm{K}$ concentration $\left(\mathrm{g} \mathrm{Kg}^{-1}\right)$ and uptake $\left(\mathrm{Kg} \mathrm{fed}^{-1}\right)$ in the seeds of peanut plants presented in Table (6) show that, the plants inoculated with the liquid Bradyrhizobium sp. 3339 during FW of sowing, led to high increases in of $K$ contents the seeds compared to the other inoculation treatments. The seeds of peanut plants of NC gained higher $\mathrm{K}$ contents in compared to those found with the plants of Ponch cultivar.

Rates of the RC, \%of potassium uptake in seed of peanut plants listed in Table (6) reveal that, plants inoculated with the liquid Bradyrhizobium sp. during FW and SW of sowing, had higher RC value of $K$ uptake in compared to the solid inoculation treatments. The maximum RC \% values of $K$ uptake were obtained in seed of peanut plants inoculated with the liquid Bradyrhizobium sp. during of FW after sowing, where these values were: 77.37 and $\mathbf{1 0 0 . 1 8 \%}$ for Ponch and NC cultivars, respectively.

Results of the current study showed that application of the specific strains i.e. Bradyrhizobium spp 3339, during FW and SW of sowing, significantly improved the uptake of macro nutrients $(\mathrm{N}, \mathrm{K}, \mathrm{P})$ in peanut plants relative to the solid inoculation" "SI" and the later liquid inoculation during TW of sowing, which had lower macronutrients uptake. It is clear that high shoot nitrogen content in inoculated studied plants is due to biological nitrogen fixation which made nitrogen readily available for plants uptake. The increased uptake of major elements in the plant inoculated indicate the necessity of using these microorganisms in agricultural systems. Before that Nyoki and Ndakidemia, 2018 reported the improved uptake of plant nutrients following Rhizobium inoculation. The mechanisms of this improved uptake of nutrients in Rhizobium inoculated peanut are still not clear, however, it is thought that these microorganisms can change the soil $\mathrm{pH}$ to the level which favor the uptake of plant nutrients (Ndakidemi et al., 2011). The competition between inoculants (Rhizobia) and native soil strains for nodule occupancy is an important factor affecting successful symbiosis, particularly for common bean, which usually responds poorly to inoculation owing to its promiscuous nodulation with competitive but inefficient resident rhizobia resulting in deficient nodulation and low nitrogen fixation rates (PastorBueis et al., 2019). The use of liquid inoculation for successive 7 days $\mathrm{FW}$ and at SW of sowing, consequently adding huge number of rhizobia on the seeds practically at the early germination stage were more effective competitive, and adapted strains to inoculate peanut plants, such as the specific Bradyrhizobial strains compared to the solid inoculation or the late liquid inoculation at TW.

Therefore, the higher nodulation ability of liquid inoculation with Bradyrhizobium spp 3339 during FW of sowing may represent a competitive advantage for nodule occupation peanut plants in this study in the presence of indigenous soil rhizobia and represent and additional advantage as compared to the late application of liquid Bradyrhizobium spp 3339 , or the solid inoculation (SI). These successive early application during FW of sowing, should be subjected to further analysis within early 7 days of sowing of their nodulation competitiveness and symbiotic performance under field conditions to 
confirm this potential. In rhizobia, their cell motility, production of exopolysaccharides, and phytohormones can affect the success of symbiosis and the efficiency of BNF (Raina et al., 2019).

As an outlook at the results of the nodule number, dry matter yield $N, P, K$, contents in peanut shoot plants, and seeds (Tables 2 to 6 ), the following orders are inferred, as affected by solid or liquid inoculation by of Bradyrhizobium spp. 3339:

- For inoculation treatments: Liquid inoculation during $\mathrm{FW}>$ Liquid inoculation during SW > solid Inoculation "SI" > Liquid inoculation during studied treatment was"TW". For peanut cultivars the response for the NC > Ponch cultivar.

\section{REFERENCES}

Bashan, Y., L.E. de-Bashan, S.R. Prabhu and J.P. Hernandez (2014). Advances in plant growth-promoting bacterial inoculant technology: formulations and practical perspectives (19982013). Plant Soil, 378: 1-33.

Brockwell, J., P.J. Bottomley and J.E. Thies (1995). Manipulation of rhizobia microflora for improving legume productivity and soil fertility: a critical assessment. Plant Soil 174: 143-180.

Chapman, H.D. and P.F. Pratt (1961). Methods of analysis for soils, plants and waters. University of California, Los Angeles, 60-61: 150-179.

Cottenie, L., M. Verloo, L. Kiekens, G. Velghe and R. Camerlyck (1982). Chemical Analysis of Plants and Soils. In "Laboratory Analysis and Geochemistry." State Univer., Ghent. Belguium.

Deaker, R., J.R. Roughley and R.I. Kennedy (2004). Legume seed inoculation technology. a review. Soil Biology \& Biochemistry, 36: 12751288.
El-Sayed, S., M. El-Howeity, S. ElHendawy and U. Sehmidhalter (2016). Non-invasive spectral detection of the beneficial effect of Bradyrhizobium and plant growth -promoting Rhizobacteria under different levels of nitrogen application on the biomass, nitrogen status, and yield of peanut cultivars. J. Bragantia.

El Zemrany, H. M., G. A. A. Mekhemar and S. S. Abd El Salam (2019). Evalution efficency of liquid Bradyrhizobium and Azotobacter chroococcum DSM 2286 as co-inoculation affected by salinity level of irrigation water on peanut in sandy soils of Egypt. Menoufia J. Soil Science, 4: 201-217.

Gomez, K.A. and A.A. Gomez (1984). Statistical Procedures for Agricultural Research. 2nd ed., International Rice Research Institute, College, Laguna, 680pp.

Klute, A. (1986). Methods of Soil Analysis, Part 2: Physical and Mineralilogical Properties. Amer. Soc. Agron. Inc. Madison, Wise., USA.

Kyei-Boahen, S., A.E. Slinkard and F.L. Walley (2002). Evaluation of Rhizobial Inoculation methods for chickpea. Agron. J. 94: 851- 859

Naveed, M., I. M. Mehboob, B. Hussain and A.Z. Zahir (2015). Perspectives of Rhizobial Inoculation for Sustainable Crop Production. K. Arora (ed.), Plant Microbes Symbiosis: Applied Facets, 209 DOI 10.1007/978-81-322-2068-8_11, (c) Springer India.

Ndakidemi, P.A., Bambara S. and J.H.J.R. Makoi (2011). Micronutrient uptake in common bean (Phaseolus vulgaris L.) as affected by rhizobium inoculation, and the supply of molybdenum and lime. Plant Omics 4 (1): 40-52.

Nyoki, D. and P. A. Ndakidemia (2018). Rhizobium inoculation reduces $P$ and $K$ fertilization requirement in corn soybean Intercropping. Rhizosphere 5 
(2018)

https://doi.org/10.1016/j.rhisph.

2017.12. 002

Page, A.L., R.H. Miller and D.R. Keeney (1982). Methods of Soil Analysis: Part 2. Chemical and Microbiological Properties, $2^{\text {nd }}$ ed. Agronomy, vol. 9 ASA, SSSA Publishing, Madison.

Pastor-Bueis, R.P., C. SánchezCañizares, E.K. James and F. González-Andrés (2019). Formulation of a Highly Effective Inoculant for Common Bean Based on an Autochthonous Elite Strain of Rhizobium leguminosarum bv. phaseoli, and Genomic-Based Insights Into Its Agronomic Performance. Front. Microbiol. 10:2724. doi: 10.3389/fmicb.2019.02724

Raina, J.B., V. Fernandez, B. Lambert, R. Stocker and J.R. Seymour (2019). The role of microbial motility and chemotaxis in symbiosis. Nat. Rev. Microbiol, 17: 284-294. https://doi.org/10. 1038/s41579-0190182-9.

Schulz, T.J. and K.D. Thelen (2008). Soybean seed inoculant and fungicidal seed treatment effects on soybean. Crop Sci., 48:1975-1983

Singleton, P., H. Keyser and E. Sande (2002). Development and Evaluation of
Liquid Inoculants, in: Herridge, D. (ed.) Inoculants and Nitrogen Fixation of Legumes in Vietnam. ACIAR Proceedings 109e, Canberra, pp 5266.

Vincent, J. M. (1970). A Manual for The Practical Study of The Root Nodule Bacteria IBP 15. Black Well Scientific Publications Oxford and Edinburgh. U.K., p 146.

Yates, R.J., R. Abaidoo and J.G. Howieson (2016). Field Experiments with Rhizobia. In: Howieson, J. Dilworth, M. (ed.) Working with rhizobia, Australian Centre for International Agricultural Research, Canberra, pp. 145-166.

Zhang, W., H.W. Wang, X.X. Wang, X.G. Xie, M.D.A. Siddikee, X.U. Ri-Sheng and C.CV. Dai (2016). Enhanced nodulation of peanut when coinoculated with fungal endophyte Phomopsis liquidambari and bradyrhizobium. Plant Phys. Biochem, 98:1-11. doi: 10.1016/j.plaphy. 2015.11.002. Epub 2015 Nov 4.

Zommere, Z. and V. Nikolajeva (2017). Immobilization of bacterial association in alginate beads for bioremediation of oil-contaminated lands. Environ. Exp. Bot., 15: 105-111. 
التوقيت الامثل للتلقيح بـ BRADYRHIZOBIUM SP 3339 على كفاءة التعقيد ونمو الفول السوداني في أرض رملية حديثة الإستصلاح

حمدي الزمراني(1)، الحسيني عبد الغفار (بوحسين(1)، علاء الدين ابو السعود(2)،

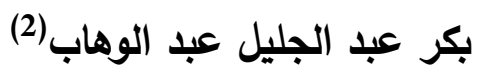

(1) جامعة المنوفية - كلية النزراعة - قسم علوم الأراضي

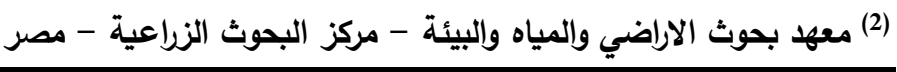

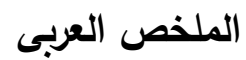

تم إجراء هذا البحث لتقييم تأثير توقيت التلقيح السائل بـ Bradyrhizobim sp 3339 علي إثنين من اصناف الفول السوداني على عملية التعقيد ونمو النبات وجودة المحصول. أجريت تجربة حقلية في قرية أم صابر - منطقة

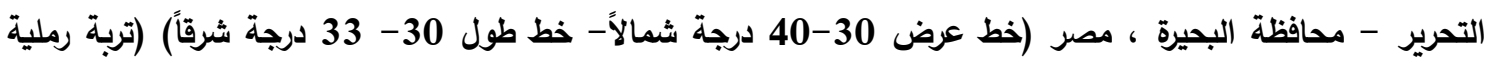

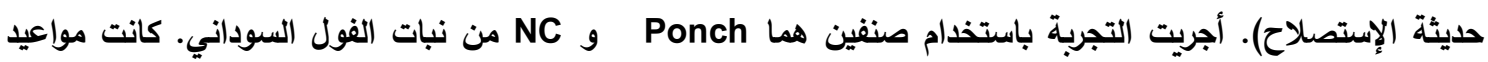

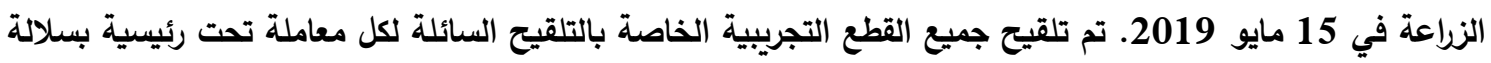
Bradyrhizobim sp 3339

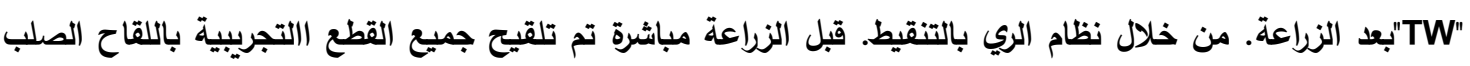

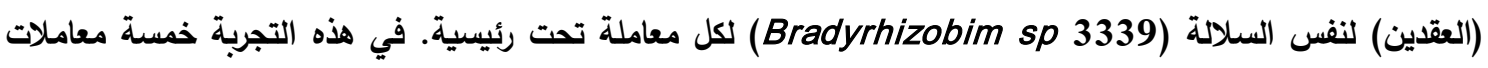

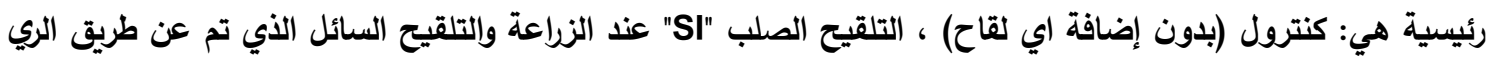

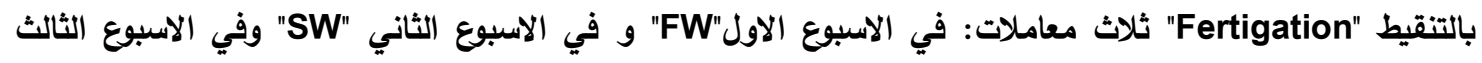

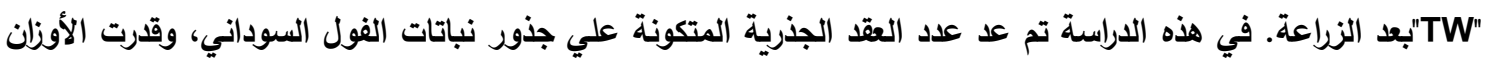



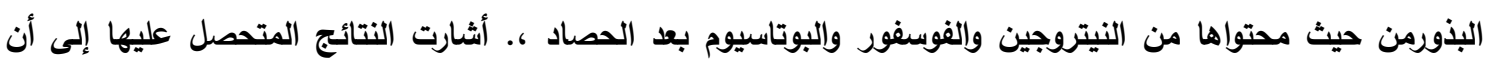

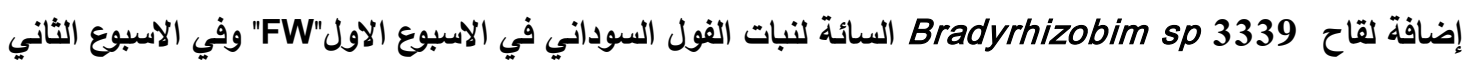

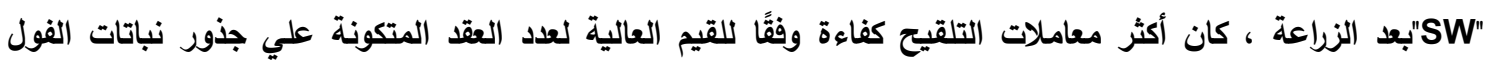

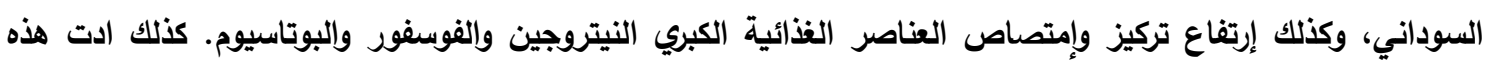

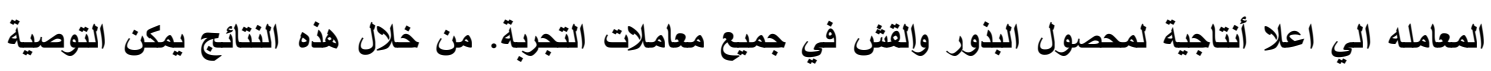

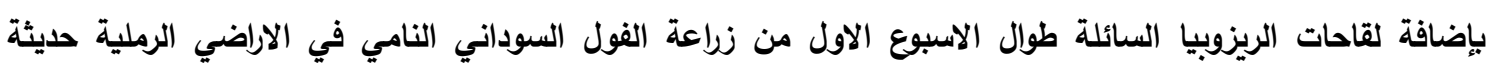
الاسصلاح في مصر .

أسماء السادة المحكمين

معهة البيئة الصحراوية - جامعة السادات

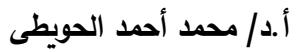

أ.د/ فاطمة سعد الثافعى كلية الزراعة - جامعة المنوفية 